Gut, 1973, 14, 316-318

\title{
Bile acids and vitamin A absorption in man: the effects of two bile acid-binding agents, cholestyramine and lignin
}

\author{
D. L. BARNARD ${ }^{1}$ AND K. W. HEATON ${ }^{2}$ \\ From the Department of Pathology, Bristol Royal Infirmary, and Department of Medicine, University of \\ Bristol
}

SUMMARY In 14 healthy volunteers, the addition of $12 \mathrm{~g}$ cholestyramine to a vitamin A-containing test meal reduced the expected rise in serum vitamin $\mathrm{A}$ by $59.5 \%(\mathrm{P}<0.001)$. By contrast, lignin had no significant effect in 12 subjects. This study confirms the importance of bile acids in vitamin A absorption and the ineffectiveness of lignin as a sequestrator of conjugated bile acids.

It is generally accepted that the absorption of fatsoluble vitamins is dependent on the presence of a micellar phase and hence of conjugated bile acids in the intestinal lumen (Hofmann, 1968; Heaton, 1972). It is also well documented that cholestyramine binds conjugated bile acids both in vitro (Johns and Bates, 1970) and in vivo (Kenney and Garbutt, 1970; Heaton, Heaton, and Barry, 1971). Lignin, a natural phenylpropane polymer present in plant fibre, has undoubted, if rather slow, bile acid-binding activity in vitro, this activity being greater with free than with conjugated bile acids (Eastwood and Hamilton, 1968). Clinical experience in a small number of cases has suggested that lignin may be effective in two disorders in which cholestyramine is very useful, namely, type II hyperlipoproteinaemia and postileectomy diarrhoea (Thiffault, Bélanger, and Pouliot, 1970; Eastwood and Girdwood, 1968). However, it has not yet been shown that lignin sequestrates conjugated or free bile acids in vivo. In a previous study in normal subjects, we were unable to detect any effect of lignin on the recirculation of radioactively labelled taurocholate and its metabolites (Heaton et al, 1971).

The present study was designed to re-assess whether lignin binds conjugated bile acids in vivo by observing its effect on vitamin $\mathbf{A}$ absorption, as measured by the vitamin A tolerance test. For

${ }^{1}$ Present address: Department of Haematology, Western General Hospital, Edinburgh

2Reprint requests to Dr K. W. Heaton, University Department of Medicine, Bristol Royal Infirmary, Bristol BS2 8HW.

Received for publication 17 January 1973. comparison, cholestyramine was studied in the same way. It was expected that cholestyramine would have an easily detectable effect, although scant data have been published on how this agent affects vitamin A absorption (Longenecker and Basu, 1965).

\section{Methods}

DESIGN OF THE STUDY

Healthy volunteers of both sexes aged 19-28 were studied, each acting as his or her own control. Most subjects received three test meals, given in random order at intervals of not less than a week. Fourteen subjects received a control test meal and one containing cholestyramine. Twelve subjects also received a test meal containing lignin.

After an overnight fast the test meal was consumed within 10 minutes. Venous blood samples, taken immediately before the meal and again at four, five, and six hours, were kept in the dark until analysis on the same day.

\section{PREPARATION OF TEST MEALS}

A stock solution of vitamin A was prepared by adding $1 \mathrm{~g}$ vitamin A palmitate (Oily Preparation, Roche, containing $10^{6} \mathrm{iu} / \mathrm{g}$ ) to $99 \mathrm{~g}$ arachis oil and mixing thoroughly. This solution was found to keep satisfactorily for several weeks at $4^{\circ} \mathrm{C}$ in the dark, but the concentration of vitamin A was checked immediately before preparing the test meal. Each test meal contained 5000 iu vitamin A per kilogram body weight, $0.5 \mathrm{~g} / \mathrm{kg}$ Casilan, $0.5 \mathrm{~g} / \mathrm{kg}$ glucose, and $5 \mathrm{~g} / \mathrm{kg}$ water. No additions were made to the control test meal, but to the other test meals either $12 \mathrm{~g}$ of 
lignin (Therapharm Ltd) or $12 \mathrm{~g}$ of cholestyramine (in the form of Questran $27 \mathrm{~g}$ ) were added. All test meals were thoroughly homogenized immediately before being taken.

\section{ESTIMATION OF INCREASE IN SERUM VITAMIN A}

A simple method was used which depends on there being no change in the serum level of other heptaneextractable compounds that absorb at $327 \mathrm{~nm}$ during the period of the test. Studies on 120 patients using this method gave results identical with those obtained by measuring the absolute levels of vitamin A (Chawla and Wiggins, 1969). Absolute alcohol, $4.0 \mathrm{ml}$, was added to $2.0 \mathrm{ml}$ of serum in a glassstoppered tube and the contents mixed. Heptane, $4.0 \mathrm{ml}$, was then added and the tube shaken on an automatic shaker for 10 minutes. The tube was centrifuged and the absorbence of the upper heptane phase containing the vitamin A was read at $327 \mathrm{~nm}$. The difference between the absorbence at four, five, and six hours and that of the fasting sample was divided by 0.00031 to give a curve for the rise in serum vitamin A in IU per $100 \mathrm{ml}$. All estimates were made in duplicate and showed good agreement.

The possibility that lignin breakdown products are absorbed and give rise to significant heptaneextractable serum absorbence at $327 \mathrm{~nm}$ was investigated in two subjects. This absorbence was measured before, and four, five, and six hours after, ingestion of a test meal containing $12 \mathrm{~g}$ lignin but no vitamin A. No change in absorbence was noted in either subject.

The possibility that cholestyramine and lignin bound vitamin $A$ in the test meal was investigated by studies in vitro. Standard vitamin A test meals were prepared with and without cholestyramine. After standing for four hours, the mixtures were rehomogenized and aliquots were extracted with heptane and their absorbence was measured at $327 \mathrm{~nm}$. Identical readings were obtained whether or not cholestyramine was present in the test meal. Similarly, the presence of cholestyramine made no difference to the readings when phosphate buffers of $\mathrm{pH} 5$ and $7 \cdot 6$, homogenized with vitamin $\mathbf{A}$ in arachis oil, were used in place of the test meal. Parallel studies with lignin gave the same results.

\section{Results}

In most subjects given a control test meal the peak serum vitamin A level was observed at five hours, but in a few cases at four or six hours after ingestion of the meal. The timing of the peak was unchanged when lignin or cholestyramine was added to the test meal.
In 14 subjects the five hour increase in serum vitamin A was measured with and without cholestyramine (fig 1). The increase with cholestyramine was

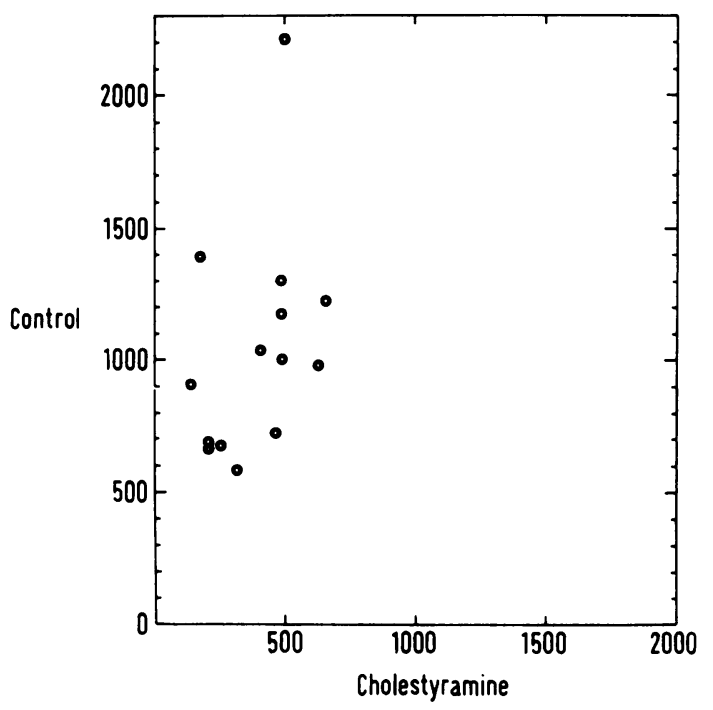

Fig 1 The effect of cholestyramine on the five-hour rise in serum vitamin $A$ in 14 subjects. The result for a control test is plotted against the result when cholestyramine $12 \mathrm{~g}$ was added to the test meal. The scale indicates international units of vitamin $A$.

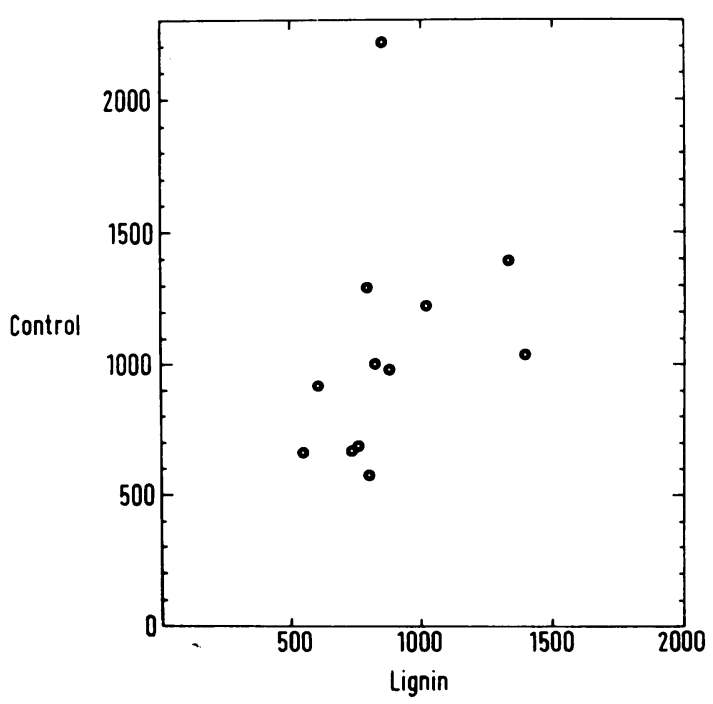

Fig 2 The effect of lignin on the five-hour rise in serum vitamin $A$ in 12 subjects. The result for a control test is plotted against the result when lignin $12 \mathrm{~g}$ was added to the test meal. The scale indicates international units of vitamin $A$. 
smaller in all subjects, markedly so in most cases. The mean increase with cholestyramine was $40.5 \pm$ $17.0 \%$ of the increase for the control test $(t=13.07$, $\mathrm{P}<0.001$ ).

In 12 subjects the five hour increase in serum vitamin A was measured with and without lignin (fig 2). The increase with lignin was smaller in eight and larger in four subjects. Overall, no significant difference was found. The mean increase with lignin was $93.2 \pm 29.5 \%$ of the control test increase $(\mathrm{t}=$ 0.798).

If the data are calculated using the peak rise (that is, the highest of the four, five, and six hour values) instead of the five hour rise in serum vitamin A, lignin again produced no significant change, whereas cholestyramine caused a highly significant reduction (mean value with cholestyramine $40.4 \pm 15.4 \%$ of the control value; $\mathrm{t}=14.48, \mathrm{P}<0.001$ ).

\section{Discussion}

In this study we have shown that cholestyramine, in an amount equivalent to a modest daily dose, markedly reduces vitamin $\mathbf{A}$ absorption as assessed by the vitamin $\mathrm{A}$ tolerance test. It acts presumably by removing bile acids from solution and so preventing the formation of a micellar phase in the small bowel lumen. This finding was predictable and confirms earlier preliminary studies (Longenecker and Basu, 1965). Although cholestyramine is not very palatable, it is unlikely that delayed gastric emptying played a significant role since adding this agent to the test meal did not delay the peak rise in serum vitamin $\mathbf{A}$.

It is probable that cholestyramine also impairs the absorption of the other fat-soluble vitamins D, E, and $\mathrm{K}$. Direct studies of this question are lacking, but cases are on record in which cholestyramine appeared to cause osteomalacia (Heaton, Lever, and Barnard, 1972) and hypoprothrombinaemia (Gross and Brotman, 1970), which were reversed by treatment with vitamins $D$ and $K$ respectively.

Although the vitamin A tolerance test is crude and unphysiological, the results with cholestyramine show that it can be used to detect pharmacological binding of conjugated bile acids. The failure of lignin, even when given in an amount two or three times greater than the suggested daily dose (Thiffault et al, 1970; Eastwood and Girdwood, 1968), to have any significant effect on the rise in serum vitamin $A$ suggests that in vivo lignin does not bind conjugated bile acids to an important extent. A similar conclusion was reached in a previous study in which lignin failed to accelerate the removal from the enterohepatic circulation of labelled taurocholate and its metabolites (Heaton et al, 1971).

Small-scale studies have led to the claim that lignin is effective in lowering elevated serum cholesterol levels (Thiffault et al, 1970) and in relieving the bile acid catharsis of ileal resection (Eastwood and Girdwood, 1968). If these effects are substantiated, the mode of action of lignin must be different from that of cholestyramine. There are marked physicochemical differences between the two materials. Cholestyramine is a polybasic anion exchange resin which is believed to act mainly by exchanging chloride ions for bile acid ions, though a lesser non-electrostatic component has been postulated (Johns and Bates, 1970). In contrast, lignin is a relatively nonpolar, aromatic polymer, which is thought to act by hydrophobic bonding (Eastwood and Hamilton, 1968). In vitro, lignin binds most effectively the least polar bile acids and it may be speculated that any therapeutic properties of lignin are due to binding of mono-hydroxy or other bacterially degraded bile acids.

We are grateful to the medical students and technicians who volunteered for this study and to the dieticians Miss Gleghorn and Miss Martin who prepared the test meals. We are indebted to Miss E. H. L. Duncan and Mrs A. F. Morris for statistical help. Lignin, prepared from pine wood, was kindly donated by Therapharm Ltd, Downham Market, Norfolk.

\section{References}

Chawla, L. S., and Wiggins, H. S. (1969). Personal communication. Eastwood, M. A., and Girdwood, R. H. (1968). Lignin: a bile-salt sequestrating agent. Lancet, 2, 1170-1172.

Eastwood, M. A., and Hamilton, D. (1968). Studies on the adsorption of bile salts to non-absorbed components of diet. Biochim. biophys. Acta (Amst.), 152, 165-173.

Gross, L., and Brotman, M. (1970). Hypoprothrombinemia and hemorrhage associated with cholestyramine therapy. Ann. intern. Med., 72, 95-96.

Heaton, K. W. (1972). Bile Salts in Health and Disease. Churchill Livingstone, Edinburgh.

Heaton, K. W., Heaton, S. T., and Barry, R. E. (1971). An in vivo comparison of two bile salt-binding agents, cholestyramine and lignin. Scand. J. Gastroent., 6, 281-286.

Heaton, K. W., Lever, J. V., and Barnard, D. (1972). Osteomalacia associated with cholestyramine therapy for postileectomy diarrhea. Gastroenterology, 62, 642-646.

Hofmann, A. F. (1968). Functions of bile in the alimentary canal. In Handbook of Physiology, Section 6: Alimentary Canal, Vol. V: Bile; Digestion; Ruminal Physiology, edited by C. F. Code, pp. 2507-2533. American Physiological Society, Washington D.C.

Johns, W. H., and Bates, T. R. (1970). Quantification of the binding tendencies of cholestyramine. II. Mechanism of interaction with bile salt and fatty acid salt anions. J. Pharm. Sci., 59, 329-333.

Kenney, T. J., and Garbutt, J. T. (1970). Effect of cholestyramine on bile acid metabolism in normal man. (Abstr.) Gastroenterology, $58,966$.

Longenecker, J. B., and Basu, S. G. (1965). Effect of cholestyramine on absorption of amino acids and vitamin $\mathbf{A}$ in man. (Abstr.) Fed. Proc., 24, 375.

Thiffault, C., Belanger, M., and Pouliot, M. (1970). Traitement de l'hyperlipoproténémie essentielle de type II par un nouvel agent thérapeutique, la celluline. Canad. med. Ass. J., 103, 165-166. 